\title{
Effect of Drying Process on the Quality of Table Olives
}

\section{Badawy H.A.A., Susan M.M. Abd-Elmageed and Rania I.M. Almoselhy}

\author{
Oils and Fats Research Department, Food Technology Research Institute, Agricultural Research
} Center, Giza, Egypt

Received: 11 Jan. 2020 / Accepted 06 April 2020 / Publication date: 20 April. 2020

\begin{abstract}
The present work aimed to investigate the effect of drying conditions (temperature and time) on the quality of green table olives (Oleo eurapaea L.) Picual cultivar during the drying process in order to obtain the best processing conditions to avoid losses and keep product quality of table olive. Oven temperature varied from 50 to $70^{\circ} \mathrm{C}$ drying rates were determined and the proximate analysis of dried green olives was evaluated by analysis of moisture, protein, ash, fiber and oil contents. Peroxide value, acidity and fatty acids composition of extracted oil from olive samples were determined. Consumer's acceptance test was applied. A comparison of fresh and dehydrated olive showed that oven drying led to decrease of crude protein. Crude fiber content showed a slight increase during drying and may have undergone some alterations in its structure due to Maillard reactions. Ash content also showed a slight variation but may be considered as practically unchanged. Fatty acid analysis revealed that table olives were especially rich in oleic acid and the fatty acid composition did not show significantly change during drying. Olives can be considered as a product with a satisfactory microbiological quality and nutritional value with regard to bioactive ingredients. It brings about substantial reduction in mass and volume which has important economic benefits through reducing packaging and minimizes the volume of containers with maximum net weight, thereby lowering transportation costs, avoids losses and keeps high quality of longer shelf-life of table olives.
\end{abstract}

Keywords: Table olives; oven drying; dehydration; consumer's acceptability

\section{Introduction}

The olive tree is the most important tree in the world. Olive oil and table olives are consumed extensively in the Mediterranean diet. Table olives are prepared from the fruit of a variety of cultivated olive trees, and, after removing their bitterness by several methods, they are preserved by natural fermentation or other methods before packing. Currently, scientists and consumers alike are interested in and prefer fresh and healthy table olives that have been minimally and safely processed. The world production of table olives is around $10^{6} \mathrm{t}$, with approximately $80 \%$ coming from countries of the Mediterranean area. From available data (IOOC, 1998) it can be estimated that approximately $45 \%$ and $34 \%$ of the production are made up of green and black olives respectively, while the remainder is constituted of cherry color olives.

Many physical and chemical changes occurring in the fruit, such as the loss of soluble constituents and nutrients (sugars, organic acid, salt, amino acids, etc.) responsible for the typical properties of table olives, are perceived by the consumer as a loss of quality of the final product (Doymaz, 2007).

However, most processing technologies are well known and methods to control the characteristics of the olives are available. On the other hand, fermentation processes are still spontaneous, while processing technologies of oven-dried and dry-salted table olives remain completely empirical. The increasing interest of the consumers in natural products involves the use and diffusion of technologies which can offer a guarantee of preservation, hygiene and genuineness of food products (Marsilio et al., 2000).

Especially in the developed world, there is now a great demand for a wide variety of high quality dried products, with emphasis on freshness and convenience (Baysal et al., 2002). In this respect the development of new alternative products and tastes for table olives is underway. By introducing the drying techniques green table olives can be consumed as a snack food with a longer shelf-life. Water,

Corresponding Author: Susan M.M. Abd-Elmageed, Oils and Fats Research Department, Food Technology Research Institute, Agricultural Research Center, Giza, Egypt.

E-mail: susanabdelmgid76@gmail.com 
being the main component of foods, has a direct and decisive influence on their quality and shelf-life through its effect on several physicochemical and biological changes. Hot air drying is the conventional and most widely used technique for the production of dehydrated fruits and vegetables, in which heat is transferred from the hot air to the product by convection, and evaporated water is transported to the air also by convection. However, the major disadvantage associated with hot air dehydrating is the long drying time even at temperatures near $60^{\circ} \mathrm{C}$, resulting in the degradation of material quality (Nicoleti et al., 2001).

The removal of moisture prevents the growth and reproduction of microorganisms that cause decay and minimizes many of the moisture-mediated deteriorative reactions. It brings about substantial reduction in mass and volume, minimizing packaging, storage and transportation costs and makes possible storage of the product under ambient temperatures (Baysal et al., 2003).

Drying process consists of the transfer of a fluid in a solid to an unsaturated gaseous stage (Fellows, 2009). The dehydration in foam layer, lyophilization, drying in a traditional oven and vacuum and sun drying are among the most widely used methods to process fruits and vegetables (Krokida et al., 2003; Akanbi and Oludemi, 2004). The removal of moisture must be accomplished in a manner that will be least detrimental to the product quality. Several dehydration processes have been developed to maximize the use of the available conditions for the raw material as well as the energy source used (Doymaz, 2007). The dehydration of products stands out as a method to maintain the desired quality for prolonged periods (Brooks et al., 2008; Akanbi et al., 2006). In addition, drying is a classical method of food preservation; however, due to undesirable changes in quality of dried product pretreatments and drying conditions, studies are necessary (Maskan, 2000).

This study aimed to obtain the best processing conditions using drying of green table olives under different operating temperatures along with studying the changes in proximate analysis of olive samples, fatty acids composition and some physico-chemical properties of oil extracted from olive samples and consumer's acceptability.

\section{Materials and Methods}

\section{Materials}

1-Olive samples (Picual variety) were obtained from the desert road farm at Wadi El-Natrun, Beheira Governorate, Egypt.

2- Chemicals used were of analytical grade and obtained from Sigma-Aldrich Chemical Co. USA.

3- $\mathrm{NaOH}, \mathrm{NaCl}$, acetic acid and lactic acid were obtained from local market.

\section{Methods}

Olive samples (Picual variety) were calibrated (140-180 particles $/ \mathrm{kg}$ ). The flow sheet of drying process is given in Figure 1.

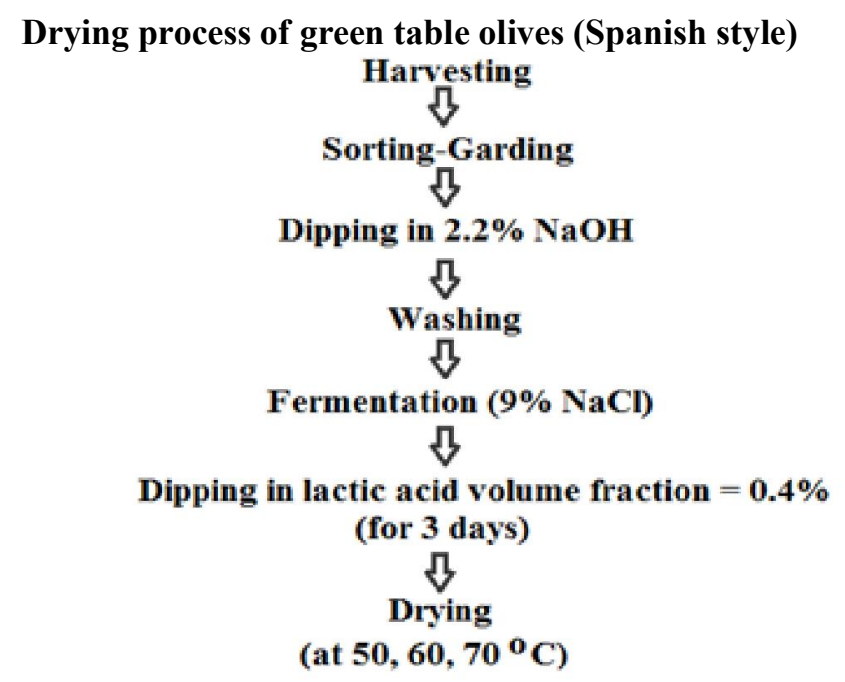

Fig. 1: Drying process of green table olives 


\section{Fermentation Process}

Fermentation was carried out in $10 \mathrm{~L}$ jar, which contained $7 \mathrm{Kg}$ of green olives. During fermentation, the mass fraction of $\mathrm{NaCl}$ in brine was initially $5 \%$ and it gradually increased to $9 \%$. Fermentation period was thirty-five days and degree of $\mathrm{pH}$ in fermentation medium was in the range of 3.8- 4.2. When the fermentation was completed, acidity and brine concentrations were kept constant during storage. Before drying, fermented green table olives were dipped into $0.4 \%$ of lactic acid to decrease salt concentration and acidity.

\section{Drying Process}

Olive samples were dehydrated by using oven dryer. In order to evaluate the effect of time and temperature on the drying process, three temperatures $\left(50,60\right.$ and $\left.70^{\circ} \mathrm{C}\right)$ were used. Leave door 2 inches to 3 inches ajar. Place a fan in front of the oven to blow air across the open door. Spread the olives in a single layer on racks or cookie sheets. Check olives frequently and turn pieces every few hours to dry more evenly. Every $60 \mathrm{~min}$. the samples were taken out, weighed and returned to the dryer. Drying stopped when the final moisture content reached 10\% (Dehydrated green olives) at the level of moisture content, can packed in plastic bags with no brine added.

\section{Proximate analysis}

Chemical compositions of green olives were expressed in dry matter. Moisture content, crude protein, fat, crude fiber, ash were determined according to the A.O.A.C. (2005), and total carbohydrates was estimated by difference.

Minerals ( $\mathrm{Na}, \mathrm{Fe}, \mathrm{K}, \mathrm{Ca}$ and $\mathrm{Mg}$ ) were determined by atomic absorption spectrophotometer after digestion in a mixture of $\mathrm{H}_{2} \mathrm{SO}_{4}, \mathrm{HNO}_{3}$ and $\mathrm{HClO}_{4}$. The mineral content was expressed in $\mathrm{mg} / 100 \mathrm{~g}$ dry matter.

Acidity (as oleic acid \%) and peroxide value (PV) meq $\mathrm{O}_{2} / \mathrm{kg}$ oil were evaluated according to the European Union Commission (1991) Regulation EEC/2568/91.

Oil extracted from olives using hexane solvent. The extracted oil was collected to study the free fatty acids and peroxide value.

\section{Determination of total polyphenols}

The total polyphenols were extracted according to the method described by McDonald et al. (2001) with slight modifications. $5 \mathrm{~g}$ of dry weight olive samples were mixed with enough $(25 \mathrm{ml})$ methanol and centrifuged at $3000 \mathrm{rpm} / 5 \mathrm{~min}$. The residue was extracted again in the same condition, and the extracts were combined, washed with hexane. The extracts were then filtered.

The total polyphenols content of the extract was determined with Folin Ciocalteu reagent according to Malik and Bradford (2006). Total polyphenol values were expressed as Gallic acid equivalents (mg/100g dry weight) from a calibration curve $(y=0,0036 x ; R 2=0.99)$.

\section{Fatty Acid Composition}

The fatty acid composition was converted into methyl ester according to ISO 12966-2:2011 (2011) and determined by GC.

\section{Consumer's acceptability}

Dehydrated samples were evaluated by a consumer's acceptability test (Meilgaard et al., 1999). Panelists were researchers of the department.

\section{Statistical analysis}

All treatments were done in triplicates and one way analysis of variance (ANOVA). and Duncan's post hoc tests were used. All hypotheses were tested at $\alpha=0.05$ significance level. All data were analyzed using SPSS (10.0) for Windows. 


\section{Results and Discussion}

\section{Drying behavior}

The experimental drying curves during drying of olives (Picual) variety at different drying temperatures are shown in Figure 2.

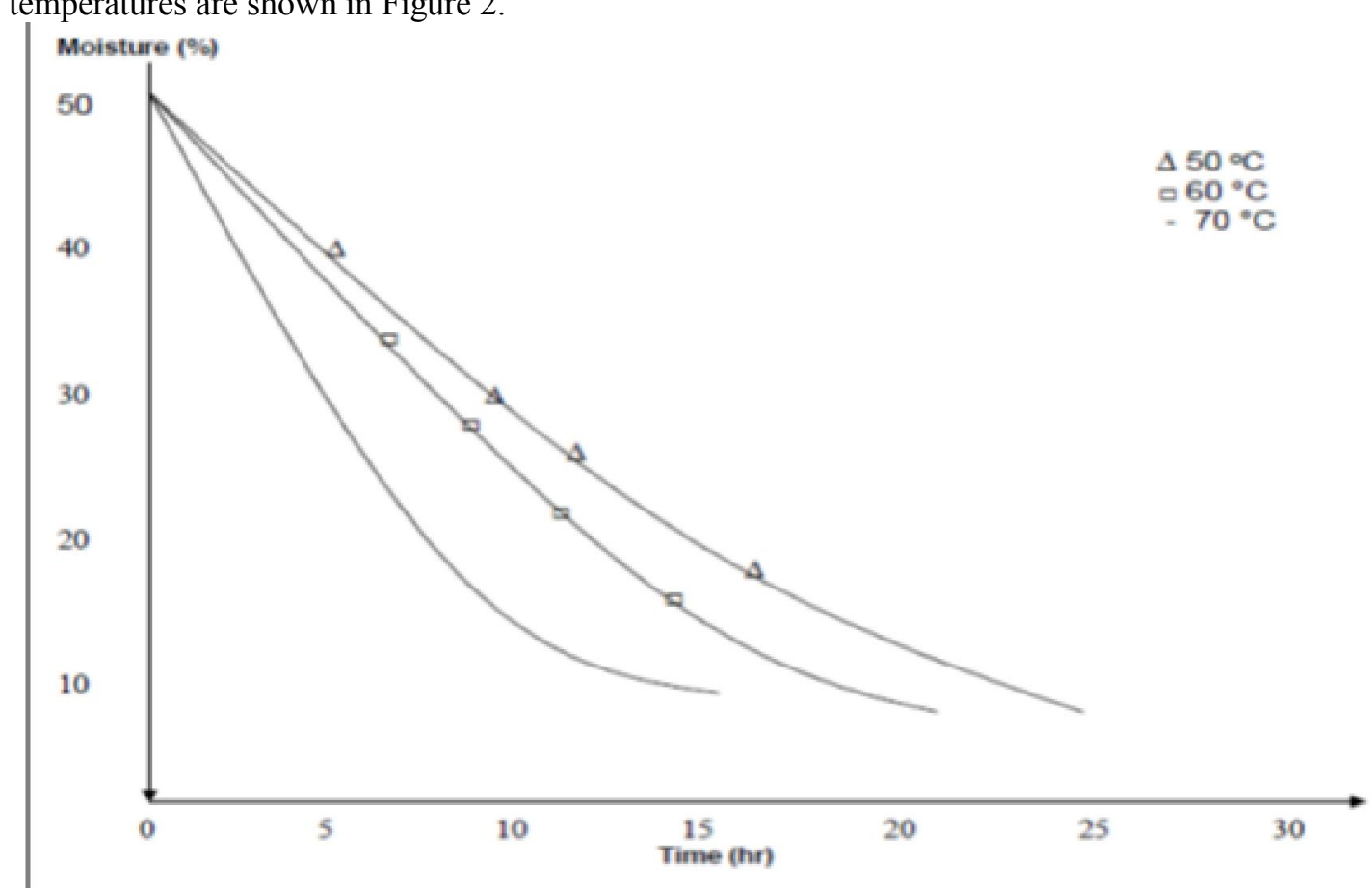

Fig. 2: Drying curves of green table olives dehydrated at different temperatures

It can be seen that moisture ratio decreases with temperature leading to shorter times at higher temperatures. Dehydration process started at $50 \%$ moisture and stopped when the moisture content of olives reached $10 \%$, which is the equilibrium moisture content. All drying curves showed an exponential tendency.

From Figure 2, drying processes at all temperatures $\left(50,60\right.$ and $\left.70^{\circ} \mathrm{C}\right)$ started at $50 \%$ till $10 \%$ moisture contents. Drying olives at $70^{\circ} \mathrm{C}$ required 16 hours, but 21 hours were needed to obtain the same moisture content at $60^{\circ} \mathrm{C}$. Finally, drying olives at $50^{\circ} \mathrm{C}$ required 25 hours. Similar effects of temperature on drying kinetics were reported in previous investigations about dehydration of olives (Göğüş and Maskan, 2006).

\section{Proximate analysis of fresh and dehydrated green Picual olives}

Table (1) shows the mean values and standard deviation of proximate analysis for both fresh and dehydrated olive samples, including moisture, crude protein, fat, crude fiber and ash contents. Carbohydrate content can be calculated by difference. Significant differences in respective contents in fresh and dehydrated samples were obtained together with homogeneous groups within the analyses samples ( $p$-value $<0.05)$.

The values of the proximate analysis of the fresh olives differ from those reported in previous works (Marsilio et al., 2000). The moisture content of fresh olives used in drying experiments was $49.29 \pm 0.7 \mathrm{~g} / 100 \mathrm{~g}$ dry matter. The crude protein content of the fresh olive was also similar to that reported by (Gaye et al., 2005). The proximate analysis also showed that ash content, which represents all minerals in the dry matter, remained as expected, practically unaltered, and no significant difference was found between the ash content of fresh and dehydrated olive.

With respect to crude protein content, the all dehydrated samples obtained were no significantly differences from one another, showing that the temperature level of the drying assays would not significantly affect the denaturation process. On the other hand, the decrease in fat content may be due to enzymatic hydrolysis during the drying period or to lipid oxidation through thermal treatment 
(Gambella et al., 2000). However, the fat content of samples did not show any significant change during drying. The high fiber content, associated with the presence of skin, pulp and stones, is an important quality attribute of olives.

The influence of drying temperature on total polyphenols compounds for fresh and dehydrated olive can be seen in Table (1). The increase in drying temperature caused a notable loss in total polyphenols compounds, leading to an evident reduction of these components, in particular at $70^{\circ} \mathrm{C}$. This observation may be explained by the fact that most phenolic compounds are heat-sensitive or labile under heat treatment (Vashisth et al., 2011). Loss of total polyphenols due to thermal degradation has been also reported by other authors (Miranda et al., 2010).

Table 1: Proximate analysis of fresh and dehydrated green Picual olives $(\mathrm{g} / 100 \mathrm{~g}$ dry matter)

\begin{tabular}{lcccc}
\hline Component & Fresh olives & $\mathbf{5 0}^{\circ} \mathbf{C}$ & $\mathbf{6 0}^{\circ} \mathbf{C}$ & $\mathbf{7 0}^{\circ} \mathbf{C}$ \\
\hline Moisture & $49.29 \pm 0.7^{\mathrm{a}}$ & $\begin{array}{c}\text { Dehydrated* } \\
\text { green olives }\end{array}$ & $\begin{array}{c}\text { Dehydrated* } \\
\text { green olives }\end{array}$ & $\begin{array}{c}\text { Dehydrated } \\
\text { green olives }\end{array}$ \\
Fat & $22.40 \pm 0.2^{\mathrm{a}}$ & $21.61 \pm 0.02^{\mathrm{b}}$ & $21.34 \pm 0.05^{\mathrm{b}}$ & $20.92 \pm 0.1^{\mathrm{ab}}$ \\
Crude protein & $5.46 \pm 0.3^{\mathrm{a}}$ & $4.13 \pm 0.4^{\mathrm{b}}$ & $4.23 \pm 0.2^{\mathrm{b}}$ & $3.89 \pm 0.3^{\mathrm{b}}$ \\
Crude fiber & $10.32 \pm 0.6^{\mathrm{a}}$ & $11.22 \pm 0.7^{\mathrm{ab}}$ & $11.61 \pm 0.8^{\mathrm{b}}$ & $12.22 \pm 0.8^{\mathrm{c}}$ \\
Crude ash & $3.40 \pm 0.5^{\mathrm{a}}$ & $3.6 \pm 0.1^{\mathrm{a}}$ & $3.55 \pm 0.4^{\mathrm{a}}$ & $3.29 \pm 0.3^{\mathrm{a}}$ \\
Carbohydrate ** & $9.13 \pm 0.5^{\mathrm{a}}$ & $10.15 \pm 0.7^{\mathrm{b}}$ & $9.98 \pm 0.5^{\mathrm{ab}}$ & $10.39 \pm 0.6^{\mathrm{b}}$ \\
Total polyphenols (mg/100g) & $1800 \pm 0.7^{\mathrm{a}}$ & $1300 \pm 0.55^{\mathrm{b}}$ & $1250 \pm 0.2^{\mathrm{bc}}$ & $1200 \pm 0.4^{\mathrm{c}}$ \\
\hline
\end{tabular}

Different letters in the same row indicate significant difference ( $\mathrm{p}$-value $<0.05$ )

(Data are expressed as average \pm standard deviation in three replicates)

* Green olives $90 \%$ dehydrated are packed in plastic bag with no brine added

** Total carbohydrates were calculated by difference

\section{Effects on fatty acid composition of oil extracted from fresh and dehydrated olives}

Table (2) summarized data of the relative fatty acid \% and composition can be seen. Statistical analysis (ANOVA) of the data indicated that some of the fatty acids found in the fresh and the dehydrated olive have slight differences in their contents $(\mathrm{p}<0.05)$.

However, overall, only slight differences were observed. Most of the fatty acids were unsaturated fatty acids, with oleic acid (73.10-74-07\%) as the predominant fatty acid. Unsaturated linoleic acid (9.86-10.34\%) had content close to that of saturated palmitic acid (11.60-12.23\%). The other fatty acids were found in small quantities (Table 2).

Table 2: Fatty acid composition of fresh and dehydrated olives (\%)

\begin{tabular}{lcccc}
\hline Fatty acid & Fresh olive & $\mathbf{5 0}^{\circ} \mathbf{C}$ & $\mathbf{6 0}^{\circ} \mathbf{C}$ & $\mathbf{7 0}^{\circ} \mathbf{C}$ \\
\hline Palmitic C16:0 & $12.10 \pm 0.05^{\mathrm{a}}$ & $12.23 \pm 0.10^{\mathrm{b}}$ & $11.98 \pm 0.25^{\mathrm{c}}$ & $11.60 \pm 0.05^{\mathrm{d}}$ \\
Palmitoleic C16:1 & $0.76 \pm 0.01^{\mathrm{a}}$ & $0.74 \pm 0.01^{\mathrm{b}}$ & $0.65 \pm 0.01^{\mathrm{c}}$ & $0.61 \pm 0.01^{\mathrm{d}}$ \\
Stearic C18:0 & $2.94 \pm 0.01^{\mathrm{ab}}$ & $2.96 \pm 0.01^{\mathrm{a}}$ & $3.01 \pm 0.03^{\mathrm{b}}$ & $3.15 \pm 0.01^{\mathrm{c}}$ \\
Oleic C18:1 & $74.07 \pm 0.07^{\mathrm{a}}$ & $73.10 \pm 0.22^{\mathrm{a}}$ & $73.48 \pm 0.10^{\mathrm{a}}$ & $73.9 \pm 0.06^{\mathrm{b}}$ \\
Linoleic C18:2 & $10.15 \pm 0.03^{\mathrm{a}}$ & $9.86 \pm 0.01^{\mathrm{b}}$ & $10.15 \pm 002^{\mathrm{c}}$ & $10.34 \pm 0.10^{\mathrm{d}}$ \\
Linolenic C18:3 & $1.02 \pm 0.01^{\mathrm{a}}$ & $1.03 \pm 0.01^{\mathrm{b}}$ & $1.15 \pm 0.01^{\mathrm{c}}$ & $1.22 \pm 0.01^{\mathrm{d}}$ \\
Arachidic C20:0 & $0.36 \pm 0.01^{\mathrm{a}}$ & $0.330 .01^{\mathrm{ab}}$ & $0.36 \pm 0.01 \mathrm{a}^{\mathrm{b}}$ & $0.35 \pm 0.01^{\mathrm{b}}$ \\
\hline
\end{tabular}

Different letters in the same row indicate significant difference $(\mathrm{p}$-value $<0.05)$

(Data are expressed as average \pm standard deviation in three replicates)

The high amount of unsaturated fatty acids, especially the high amount of oleic acid makes olive is interesting in human nutrition for its beneficial effects on blood cholesterol and other health-related outcomes (Salas et al., 2000). The nutritional value of linoleic acid is also recognized due to its metabolism at tissue levels which produce the hormone-like prostaglandins.

In general, the drying method used in this study did not cause substantial changes in the fatty acids composition. However, the quantity of total fatty acids present per gram of olive, although the quantitative composition per gram of fat did not change. The preservation of the fatty acid profile may be due to the application of relatively low heating temperature, showing that all the fatty acids present in the olive were stable within this temperature range. Any decrease in fatty acid content may be ascribed to enzymatic hydrolysis or to oxidation due to thermal treatment (Miranda et al., 2010), whereas any apparent increase may be due to probable structural changes of the dry matter. 


\section{Effects on some essential minerals of fresh and dehydrated olives}

Table (3) shows the composition of five essential minerals; iron, sodium, potassium, calcium and magnesium, in fresh and dehydrated olive at different drying temperatures. ANOVA revealed a significant difference in the mineral content of dehydrated olive when compared to fresh olive $(\mathrm{p}<0.05)$ at each drying temperature.

Table 3: Some essential minerals of fresh and dehydrated olives $(\mathrm{mg} / 100 \mathrm{~g}$ dry matter)

\begin{tabular}{lcccc}
\hline Mineral & Fresh olive & $\mathbf{5 0}^{\circ} \mathbf{C}$ & $\mathbf{6 0}^{\circ} \mathbf{C}$ & $\mathbf{7 0}^{\circ} \mathbf{C}$ \\
\hline Iron & $4.86 \pm 0.6^{\mathrm{a}}$ & $6.01 \pm 0.01^{\mathrm{b}}$ & $4.49 \pm 0.50^{\mathrm{c}}$ & $3.91 \pm 0.01^{\mathrm{d}}$ \\
Sodium & $0.73 \pm 0.01^{\mathrm{a}}$ & $0.36 \pm 0.02^{\mathrm{b}}$ & $0.38 \pm 0.01^{\mathrm{bc}}$ & $0.44 \pm 0.02^{\mathrm{c}}$ \\
Potassium & $33.85 \pm 0.22^{\mathrm{a}}$ & $11.87 \pm 0.05^{\mathrm{b}}$ & $11.78 \pm 0.01^{\mathrm{b}}$ & $11.80 \pm 0.05^{\mathrm{b}}$ \\
Calcium & $8.88 \pm 0.15^{\mathrm{a}}$ & $7.15 \pm 0.02^{\mathrm{b}}$ & $7.06 \pm 0.10^{\mathrm{b}}$ & $7.98 \pm 0.05^{\mathrm{c}}$ \\
Magnesium & $14.93 \pm 0.25^{\mathrm{a}}$ & $5.36 \pm 0.30^{\mathrm{b}}$ & $5.12 \pm 0.30^{\mathrm{b}}$ & $7.50 \pm 0.11^{\mathrm{c}}$ \\
\hline
\end{tabular}

Different letters in the same row indicate significant difference ( $\mathrm{p}$-value $<0.05$ )

(Data are expressed as average \pm standard deviation in three replicates)

In fresh olive, potassium was found to be the most abundant mineral with a value of $33.85 \mathrm{mg} / 100 \mathrm{~g}$ dry matter, while sodium was the least abundant with a value of $0.73 \mathrm{mg} / 100 \mathrm{~g}$ dry matter. This was in close agreement with that reported by (Alburquerque et al., 2004).

The potassium content in the fresh olive was also more than twice the amount found in the dehydrated samples, similar to the level of magnesium in the fresh sample that was also twice or thrice the amount found in the dehydrated samples. As for sodium, its content in the fresh sample is very near to twice the amount found in any of the dehydrated samples. On the other hand, the iron and calcium content of dehydrated samples are almost of the same order as that found in the fresh sample. A decrease in content of some specific minerals with respect to the fresh samples was observed and may be due to the diffusion of these micronutrients into intercellular spaces especially at high temperatures (Miranda et al., 2010).

\section{Effects on peroxide value and acidity}

Dried green olives contain about $22 \%$ of oil in dry basis, the quality characteristics of the oil after drying process are of importance. Peroxide value (PV) is a measure of oxidative rancidity and guide to olive oil quality. Along with the acidity it is a measure of hydrolytic rancidity (Nouros et al., 1999). As shown in Table (4), the mean values of peroxide value and acidity were found significantly different for each drying temperature $(\mathrm{p}<0.05)$. Both peroxide value and acidity of samples dried at $50^{\circ} \mathrm{C}$ have the lowest values. The highest peroxide value was obtained at $70^{\circ} \mathrm{C}$ because of the higher temperature as compared to other applications. Similar trend was observed at $60^{\circ} \mathrm{C}$, which had a higher peroxide value and acidity as compared to drying at $50^{\circ} \mathrm{C}$.

Table 4: Some chemical characteristics of fresh and dehydrated samples of olive oil

\begin{tabular}{lcccc}
\hline Parameter & Fresh olive & $\mathbf{5 0}^{\circ} \mathbf{C}$ & $\mathbf{6 0}^{\circ} \mathbf{C}$ & $\mathbf{7 0}^{\circ} \mathbf{C}$ \\
\hline Peroxide value (meq $\mathbf{O}_{2} / \mathbf{~ k g ~ o i l ) ~}$ & $4.75 \pm 0.5^{\mathrm{a}}$ & $13.33 \pm 0.8^{\mathrm{b}}$ & $14.12 \pm 0.3^{\mathrm{b}}$ & $27.50 \pm 0.5^{\mathrm{c}}$ \\
Acidity (as oleic acid \%) & $1.1 \pm 0.05^{\mathrm{a}}$ & $2.85 \pm 0.1^{\mathrm{b}}$ & $3.45 \pm 0.05^{\mathrm{bc}}$ & $6.51 \pm 0.3^{\mathrm{c}}$ \\
\hline
\end{tabular}

Different letters in the same row indicate significant difference $(\mathrm{p}$-value $<0.05)$

(Data are expressed as average \pm standard deviation in three replicates)

\section{Consumer's acceptability}

The acceptability of dried green table olives was evaluated by sensory analysis (texture, smell, taste, color, chewiness). The results of the consumer's acceptability test showed that $75 \%$ of the panelists prefer the samples dried at $50^{\circ} \mathrm{C}$ in terms of overall acceptability (texture, smell, taste, color, chewiness). This result overlaps with the experimentally determined quality characteristics of the dried green olives at $50^{\circ} \mathrm{C}$, in which the peroxide and acid values are at the lowest level.

\section{Conclusion}

It can be concluded that, the high efficiency of convective drying of table olives at optimum temperature and time which were $50^{\circ} \mathrm{C}$ for $25 \mathrm{~h}$ in drying oven to produce an excellent acceptable final product which was proven by sensory analysis. Besides, it can be stored for 1 year without the risk of deterioration. A proximate analysis of fresh and dehydrated olives showed that drying 
temperatures range caused some slight changes in overall composition $(\mathrm{p}<0.05)$. Besides the obvious decrease in moisture, denaturation of crude protein was the most noticeable change which enables dehydrated olives to be packed in plastic bags with no brine added, minor freight costs, minor handle and waste elimination costs.

\section{References}

Akanbi, C.T., and F.O. Oludemi, 2004. Effect of processing and packaging on the lycopene content of tomato products. International Journal of Food Properties, 7: 139-152.

Akanbi, C.T., R.S. Adeyemi and A. Ojo, 2006. Drying characteristics and sorption isotherm of tomato slices. Journal of Food Engineering, 73: 157-163.

Alburquerque J.A., J. Gonzalvez, D. Garcia and J. Cegarra, 2004. Agrochemical characterisation of alperujo a solid by-product of the two-phase centrifugation method for olive oil extraction. Bioresource Technology, 91: 195-200.

AOAC, 2005. Official Methods of Analysis, 14th edition Association of Official Agricultural Chemists Official Methods of Analysis. Washington DC. USA.

Baysal, T., S. Ersus and F. Icier, 2002. Effects of microwave and hot air combination drying on the quality of carrots. Food Sci. Biotechnol., 11: 19-23.

Baysal, T., F. Icier, S. Ersus and H. Yildiz, 2003. Effects of microwave and infrared drying on the quality of carrot and garlic. Eur. Food Res. Technol., 218: 68-73.

Brooks, M.S., N.H. Abou El-Hana and A.E. Ghaly, 2008. Effect of tomato geometries and air temperature on the drying behavior of plum tomato. The American Journal of Applied Sciences, 5: $1369-1375$.

Doymaz, I., 2007. Air-drying characteristics of tomatoes. Journal of Food Engineering, 78: 1291-1297.

European Union Commission, 1991. Regulation, ECC) No 2568/91. Official Journal of the European Communities, L248.

Fellows, P.J., 2009. Food Processing Technology, Woodhead Publishing Limited and CRC Press, Boca Raton, Fla, USA, 3rd edition.

Gambella, F., A. Piga, M. Agabbio, V. Vacca and G. Dhallewin, 2000. Effect of different pretreatments on drying of green table olives. Grasas y Aceites, 51: 173-176.

Gaye, O., S. Sayit, T. Derya and K. Timur, 2005. Hot air drying of green table olives. Food Technol. Biotechnol., 43 (2): 181-187.

Gögü̈ş, F., and Maskan M., 2006. Air drying characteristics of solid waste (pomace) of olive oil processing. Journal of Food Engineering, 72 (4): 378-382.

International Olive Oil Council, IOOC), 1998. international situation on table olive market and its recent evolution., 74: 26-28.

ISO 12966-2:2011, 2011. Animal and vegetable fats and oils - Gas chromatography of fatty acid methyl esters - Part 2: Preparation of methyl esters of fatty acids.

Krokida, M.K., V.T. Karathanos, Z.B. Maroulis and D. Marinos-Kouris, 2003. Drying kinetics of some vegetables. Journal of Food Engineering, 59: 391-403.

Malik, N. S., and J.M. Bradford, 2006. Changes in Oleuropein olives during differentiation and development of floral buds in Arbequina olives. Sci. Hortic. 110:274-278.

Marsilio, V., B. Lanza, C. Campestre and M. Angelis, 2000. Oven-dried table olives: Textural properties as related to pectic composition. J. Sci. Food Agric., 80: 1271-1276.

Maskan, M., 2000. Microwave/air and microwave finish drying of banana. Journal of Food Engineering, 44: 71-78.

McDonald, S., P.D. Prenzler, M. Antolovich and K. Robards, 2001. Biochemical studies on plantago major L. Farmacognosia-5-passei Direto. Food Chem., 73: 73-84.

Meilgaard, M., G.V. Civille and B.T. Carr, 1999. Sensory Evaluation Techniques, 3rd ed. CRC Press, New York, 242-245.

Miranda, M., A. Vega-Galvez, J. Lopez, G. Parada, M. Sanders and M. Aranda, 2010. Impact of airdrying temperature on nutritional properties, total phenolic content and antioxidant capacity of quinoa seeds (Chenoposium quinoa Willd.). Industrial Crops and Products, 32: 258-263. 
Nicoleti, J.F., J. Telis-Romero and V.R. Telis, 2001. Air-drying of fresh and osmotically pre-treated pineapple slices: Fixed air temperature versus fixed temperature drying kinetics. Drying Technol., 19: 2175-2191.

Nouros, P. G., C.A. Georgiou and M.G. Polissiou, 1999. Direct parallel flow injection multichannel spectrophotometric determination of olive oil peroxide value. Anal. Chim. Acta., 239: 239-245.

Salas, J.J., J. Sanchez, U.S. Ramli, A.M. Manaf, M. Willians and J.L. Harwood, 2000. Biochemistry of lipid metabolism in olive and other oil fruits. In: Prog. Lipid Res., 39:151-180.

Vashisth,T., R.K. Singh and R.B. Pegg, 2011. Effect of drying on the phenolic content and antioxidant activity of Muscatine pomace. LWT-Food Science and Technology, 44: 1649-1657. 